\title{
Citizens of the world? Children's exposure to representations of diversity, topics, text genres, and complex ideas prior to kindergarten entry
}

\author{
Maria Cahill \\ University of Kentucky \\ maria.cahill@uky.edu
}

Soohyung Joo

University of Kentucky

soohyung.joo@uky.edu

\section{Mary Howard \\ University of Kentucky \\ mary.howard@uky.edu}

\section{Introduction}

There is currently a groundswell of interest in diverse books though children's librarians have long championed diversity and inclusion (Horning, 2015). School and public librarians are genuinely passionate about exposing children to all of the world's glorious wonders and people's by diversifying library collections (Ishizuka, 2018). Thus, it seems natural that they would also expose the children they serve to a wide array of representations of diverse people, topics, and ideas through program offerings.

\section{Statement of the research problem}

Public library storytime programs support school readiness and educate parents about meaningful ways to interact with their children (Cahill et al., in press; Becker, 2012; Burger \& Landerholm, 1991; Campana et al., 2016; de Vries, 2008; McKechnie, 2006; Mills et al., 2018; Smardo, 1984; Williams, 1998). While materials used in these programs should expose children to diverse cultures, ideas, and text formats, it is unclear if that assumption holds true.

The aim of this study was to answer the following overarching research question. To what extent do public library storytime programs designed for preschoolers expose children to diverse people, topics, ideas, and text structures?

\section{Literature Review}

Storytimes are a mainstay of public library programming. Caregivers, and the children under their care, choose to attend storytimes for a variety of reasons, but prime among those are to prepare 
children for school and to develop a love of reading (Peterson, 2012). Similarly, librarians plan storytimes to support school readiness, develop a love of reading, inspire children's imaginations, and reduce feelings of isolation among caregivers and their young children (deVries, 2008; Goulding \& Crump, 2017; Kewish, 1979; McKenzie \& Stooke, 2012; Peterson, 2012; Celano \& Neuman, 2001).

Naturally, the books and materials librarians choose and use in storytimes influence the extent to which the goals of both the attendees and the librarians are met. Both the genre (Pappas, 1991; Price, Bradley \& Smith, 2012; Price, van Kleeck, \& Huberty, 2009) and the subject matter of books affect children's vocabulary (Gonzalez et al., 2011; Leung, 2008; Neuman, Kaefer, \& Pinkham, 2016) and content knowledge (Neuman, Kaefer, \& Pinkham, 2016). Moreover, the representation of characters in the books selected influences the extent to which children are able to view themselves and others who are different from them, thereby affecting children's views of themselves (Hefflin \& Barksdale-Ladd, 2001) and their interest in literacy endeavors overall (Delbridge, 2018).

Examinations of books shared in U.S. homes suggest a preference for narrative text structure (Crain-Thoreson, Dahlin, \& Powell, 2001; Kam \& \& Matthewson, 2017) while investigations of books shared and available in U.S. classrooms indicate limited representations of diversity and text formats (Crisp et al., 2016; Duke, 2000; McGill-Franzen, Lanford \& Adams, 2002; McNair, 2008; Mesmer, 2016; Pentimonti, Zucker, \& Justice, 2011; Pentimonti, Zucker, Justice, \& Kaderavek, 2010) as well as concerns about the extent to which they support vocabulary development (Mesmer, 2016). However, it is not currently clear if books shared in library programs expose children more broadly to representations of diversity, topics, text genres and formats, and/or complex ideas.

\section{Methodology}

The current study, nested in a larger, multi-state investigation of public library storytime programs designed for children ages 3- to 5-years-old, examined the print materials used in storytimes to identify the extent to which storytime exposes children to diverse people, topics, ideas, and text structures.

\section{Sample and data collection}

We invited all public libraries in the 135 counties in the three states that fall within the sampling frame for this study to participate, and then we drew a stratified random sample of 36 libraries based upon population of the legal service area and rural/urban designation.

Our research team observed and video recorded 68 storytime sessions provided by 35 public libraries and identified the 131 books shared.

\section{Data analysis}

Using content analysis methods coupled with analyses of metadata culled from the Library of Congress and World Cat catalogs, Novelist database, and Goodreads website, and textual analyses of the written texts of each of the books, we identified the genre and format, subject matter, representations of diversity, and text complexity of each of the materials.

\section{Findings}

Though currently only preliminary, our findings point to some concerns about the representations of diversity, topics, text genres and formats, and complex ideas in the materials used in public library storytime programs. Preliminary findings from this study mirror those of its classroom counterparts. First, books shared during storytime provided limited representations of children of color. Further, very few were written and/or illustrated by non-White authors and illustrators. There was a high 
prevalence of books with and about animals; and seasonal, holiday and friendship themes. Finally, storytime programs provided limited exposure to information text.

\section{Implications and Conclusions}

If school librarians are committed to global education (Hicks, 2009), "to develop information literate students who are responsible and ethical participants in society" (International Federation of Library Associations (IFLA), 2015 p. 7) by empowering them to demonstrate global perspectives and "an understanding of and commitment to inclusiveness and respect for diversity" (American Association of School Librarians (AASL), 2018), it is important for school librarians to recognize that children may be coming to school with limited exposure to diverse people, topics, ideas, and text structures. Thus, it is incumbent upon school librarians to collaborate with classroom teachers, administrators, and other school stakeholders to ensure that the curriculum as a whole "support[s] teaching and learning for all" (IFLA, 2015, p. 28) and that specific lessons and programs that the school librarian plans and teaches/offers, either alone or in collaboration with other educators, also reflects diversity in terms of representations of people, ideas, topics, and formats. Finally, it is imperative that the collections of the school libraries enable and support open and flexible access to digital and print materials that position children to gain the perspectives and knowledge of the diversity the world has to offer (AASL, 2018; IFLA, 2015).

\section{References}

American Association of School Librarians (2018). AASL standards framework for learners. Chicago: American Library Association. Retrieved from https://standards.aasl.org/wp-content/uploads/2018/08/180206-AASL-framework-for-learners $-2 . p d f$

Becker, K. (2012). 24 hours in the children's section: An observational study at the public library. Early Childhood Education Journal, 40, 107-114.

Burger, M. L., \& Landerholm, E. (1991). A library based literacy program for mothers and their preschool children. Early Child Development and Care, 70, 37-43.

Cahill, M., Joo, S., Howard, M., Ingraham Dwyer, J., King-Oaks, K., \& Yates, B.. (in press). Analysis of language use in public library storytimes. Journal of Librarianship and Information Science.

Campana, K., Mills, J.E., Capps, J.L., Dresang, E.T., Carlyle, A., et al. (2016). Early literacy in library storytimes: A study of measures of effectiveness. Library Quarterly, 86(4), 369-388.

Celano, D., \& Neuman, S. B. (2001). The role of public libraries in children's literacy development: An evaluation report. Harrisburg, PA: Pennsylvania Department of Education.

Crain-Thoreson, C., Dahlin, M. P., \& Powell, T. A. (2001). Parent-child interaction in three conversational contexts: Variations in style and strategy. New Directions for Child and Adolescent Development, 92, 23-37.

Crisp, T., Knezek, S. M., Quinn, M., Bingham, G. E., Girardeau, K., et al. (2016). What's on our bookshelves? the diversity of children's literature in early childhood classroom libraries. Journal of Children's Literature, 42(2), 29-42.

Delbridge, A. E. (2018). Mainstream and Mexican American-themed picture books and students' responses to them in a first-grade dual-immersion classroom(Unpublished doctoral dissertation). University of Minnesota, Minneapolis, MN. de Vries, P. A. (2008). Parental perceptions of music in storytelling sessions in a public library. Early childhood Education Journal, 35, 473-478.

Duke, N. K. (2000). 3.6 minutes per day: The scarcity of informational text in first grade. Reading Research Quarterly, 35(2), 202-224. 
Gonzalez, J. E., Pollard-Durodola, S., Simmons, D. C., Taylor, A. B., Davis, M. J., Kim, M., \& Simmons, L. (2011). Developing low-income preschoolers' social studies and science vocabulary knowledge through content-focused shared book reading. Journal of Research on Educational Effectiveness, 4(1), 25-52.

Goulding, A., \& Crump, A. (2017). Developing inquiring minds: Public library programming for babies in Aotearoa New Zealand.Public Library Quarterly, 36(1), 26-42.

Hefflin, B. R., \& Barksdale, M. A. (2001). African American children's literature that helps students find themselves: Selection guidelines for grades K-3. The Reading Teacher, 54(8), 810-819.

Hicks, D. (2009). A rationale for global education. UNESCO. Retrieved from http://www.unesco.org/education/tlsf/mods/theme_c/popups/mod18t05s02.html

Horning, K. T. (2015). Milestones for diversity in children's literature and library services. Children \& Libraries, 13(3), 7-11.

International Federation of Library Associations and Institutions. School Libraries Section Standing Committee. (2015). IFLA school library guidelines. Netherlands: Author. Retrieved from https://www.ifla.org/files/assets/school-libraries-resource-centers/publications/ifla-school-libr ary-guidelines.pdf

Ishizuka, K. (2018, October 22). Can diverse books save us? In a divided world, librarians are on a mission. School Library Journal. Retrieved from https://www.slj.com/?detailStory=can-diverse-books-save-us

Kam, C. L. H., \& Matthewson, L. (2017). Introducing the Infant Bookreading Database (IBDb). Journal of Child Language 44, 1289-1308.

Kewish N. (1979). South Euclid's pilot project for two-year-olds and parents. School Library Journal, 25(7), 93-98.

McGill-Franzen, A., Landford, C., \& Adams, E. (2002). Learning to be literate: A comparison of five early childhood programs. Journal of Educational Psychology, 94(3), 443-464.

McKechnie, L. E. F. (2006). Observations of babies and toddlers in library settings. Library Trends, $55,190-201$.

McKenzie, P. J., \& Stooke, R. K. (2007). Producing storytime: A collectivist analysis of work in a complex communicative space. The Library Quarterly: Information, Community, Policy, 77, $3-20$.

McNair, J. C. (2008). The representations of authors and illustrators of color in school-based book clubs. Language Arts, 85(3), 193-201.

Mesmer, H. A. E. (2016). Text matters: Exploring the lexical reservoirs of books in preschool rooms. Early Childhood Research Quarterly, 34, 67-77.

Mills, J. E., Campana, K., Carlyle, A., Kotrla, B., Dresang, E. T., et al. (2018). Early literacy in library storytimes, part 2: A quasi-experimental study and intervention with children's storytime providers. Library Quarterly, 88(2), 160-176.

Neuman, S. B., Kaefer, T., \& Pinkham, A. M. (2016). Improving low-income preschoolers' word and world knowledge: The effects of content-rich instruction. The Elementary School Journal, 116(4), 652-674.

Pappas, C. C. (1991). Fostering full access to literacy by including information books. Language Arts, 68(6), 449-462.

Pentimonti, J. M., Zucker, T. A., \& Justice, L. M. (2011). What are preschool teachers reading in their classrooms? Reading Psychology, 32, 197-236.

Pentimonti, J. M., Zucker, T. A., Justice, L. M., \& Kaderavek, J. N. (2010). Informational text use in preschool classroom read-alouds. The Reading Teacher, 63(8), 656-665.

Peterson, S. S. (2012). Preschool early literacy programs in Ontario public libraries. Partnership: The Canadian Journal of Library and Information Practice and Research, 7(2), 1-21. 
Price, L. H., Bradley, B. A., \& Smith, J. M. (2012). A comparison of preschool teachers' talk during storybook and information book read-alouds. Early Childhood Research Quarterly, 27, 426-440.

Price, L. H., van Kleeck, A., \& Huberty, C. J. (2009). Talk during book sharing between parents and preschool children: A comparison between storybook and expository book conditions. Reading Research Quarterly, 44(2), 171-194.

Smardo, F.A. (1984). Storyhours do make a difference. Texas Libraries, 45(2), 52-56.

Williams, A.J. (1998). Providers perceptions of public library storytime: A naturalistic inquiry. (Unpublished doctoral dissertation). University of Texas, Austin.

\section{Biographical Information}

Maria Cahill is an associate professor at the University of Kentucky. Her research focuses on the literacy development of children and adolescents within the context of libraries.

Soohyung Joo is an assistant professor in the School of Information Science at the University of Kentucky. His areas of research include human-information interaction, applied data science, textual analysis, and social media.

Mary Howard is director of Child Care Aware of Kentucky, Human Development Institute, University of Kentucky. She focuses on research to inform policy to practice and define quality early education environments. 